\title{
Oceanographic features of the Indian Ocean sector of Coastal Antarctica
}

\section{(Short Communication)}

\author{
Alvarinho J. Luis \\ National Centre for Polar and Ocean Research, Ministry of Earth Sciences, Headland \\ Sada, Vasco-da-Gama, Goa-403804, India
}

\begin{abstract}
A review is presented on physical oceanographic features based on expendable CTD data collected in the Indian Ocean sector of the Southern Ocean. The thermohaline structure is dominated by Circumpolar Deep Water. The temperature and salinity are affected by cyclonic circulation in the Weddell Sea and Prydz Bay. High chlorophyll-a blooms (2-4 $\mathrm{mg} \mathrm{m}^{-3}$ ) evolve during austral summer due to stratification which is caused by freshwater generated from the sea ice melt and the glacial outflow which traps phytoplankton in a shallow mixed layer, where they are exposed to higher irradiances of photosynthetically active radiation. Attempts have been made to relate the physical characteristics to biomass inferred from data published from previous Indian Scientific expeditions. More in-situ observations related to biophysical and chemical are recommended in the near future projects.
\end{abstract}

Key words: Indian Ocean sector, oceanography, water masses, circulation, hydrography, chlorophyll-a

\begin{abstract}
Abbreviations:
AABW - Antarctic Bottom Water; Chl- $a$ - chlorophyll-a; CDW - Circumpolar Deep Water; IPY - International Polar Year; MLD - Mixed Layer Depth; PAR - Photosynthetically Active Radiation; PP - Primary Production; SAM - Southern Annular Mode; SO - Southern Ocean; WG - Weddell Gyre; XCTD - Expendable Conductivity, Temperature and Depth
\end{abstract}

DOI: $10.5817 / \mathrm{CPR} 2020-1-10$

Received May 1, 2020, accepted July 24, 2020.

*Corresponding author: A. J. Luis <alvluis1@gmail.com>

Acknowledgements: Motivation for research by NCPOR Director is acknowledged. The participant of 2019 Indian Scientific expedition to Antarctica Mr Kiledar Tomar is acknowledged for data collection. This is NCPOR contribution: J- 41/2020-21. The XCTD probes were financed by the Ministry of Earth Sciences, Govt. of India, New Delhi. 


\section{Introduction}

The Southern Ocean (SO) plays a major role in water mass formation, storage and transport of heat, freshwater and carbon dioxide throughout the world oceans. In spite of its importance to global climate, the SO is the least studied domain because of data scarcity. However, the Weddel Gyre (WG), which is situated in the Atlantic sector of the SO, has been reviewed recently (Vernet et al. 2019). International Polar Year (IPY) presented an opportunity to launch field campaigns to the seas around the icy continent to record oceanographic data to fill up the data void. The Indian Scientific Expedition to Antarctic provides an opportunity to Polar researchers in India to carry out some observations in the southwest Indian Ocean sector during austral summer along the ship transect. Hy- drographic data collection program was initiated from 2006-07 using XCTD probes (make: Tsurumi Seiki Company Limited, model: XCTD-3; terminal depth: $1000 \mathrm{~m}$; temperature accuracy: $\pm 0.02^{\circ} \mathrm{C}$ and salinity accuracy: $\pm 0.03 \mathrm{mS} \mathrm{cm}{ }^{-1}$ ) which were launched from a cargo ship heading towards Antarctica to replenish supplies to Bharati and Maitri stations. Data on vertical profiles of temperature, salinity were recorded using XCTD-2 probes and surface atmospheric variables were gathered along the ship track from Cape Town to the Prydz Bay, the Prydz Bay to the Lazarev Sea, and back to Cape Town, during December to March of the following year. A review is presented here for the coastal Antarctic region spanning $10^{\circ} \mathrm{E}$ to $78^{\circ} \mathrm{E}$ (Fig. 1).

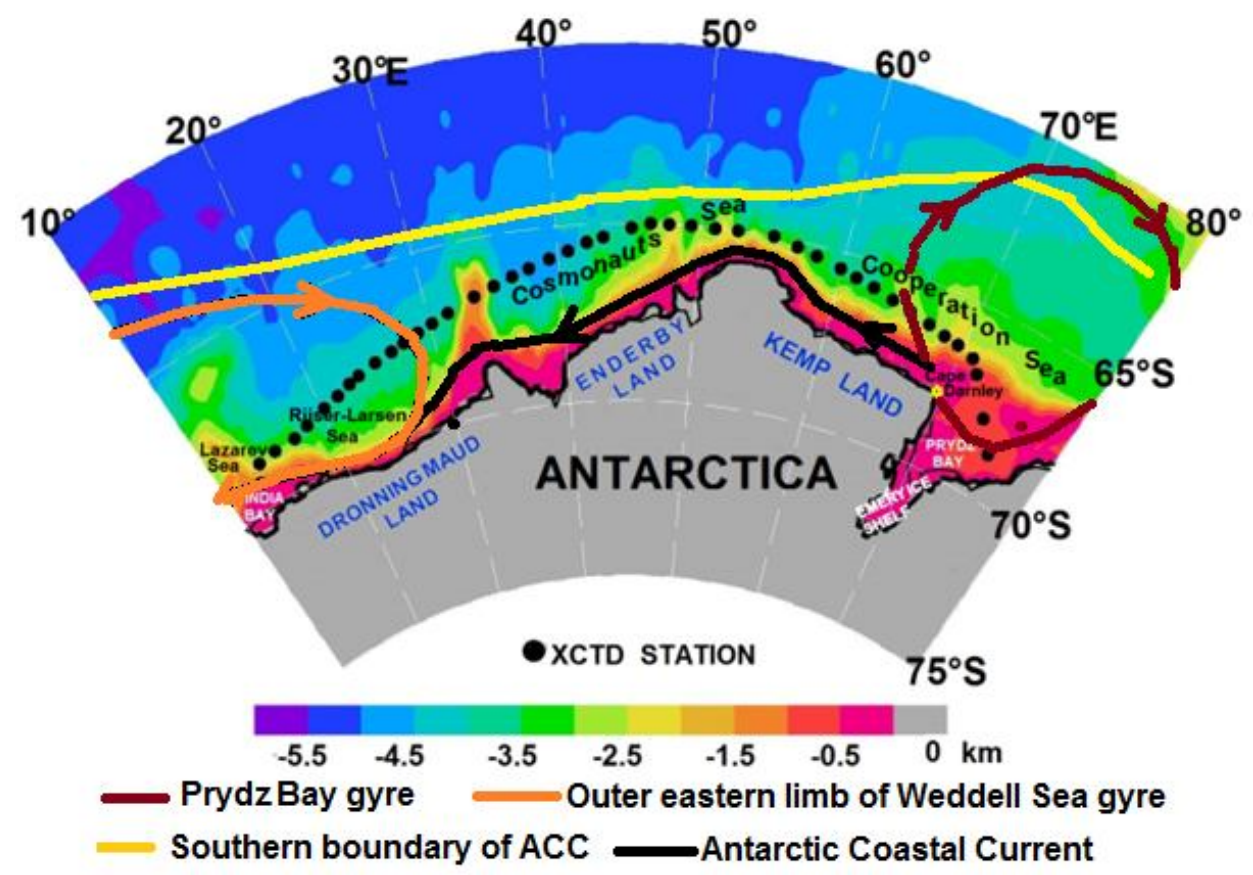

Fig. 1. Geographic features and bathymetry of the study area. The XCTD stations are shown by filled circles. 
The focus of the review is the ocean domain that extends from the Lazarev Sea in the west to the Prydz Bay to the east. Lazarev Sea extends from $0^{\circ}$ to $14^{\circ} \mathrm{E}$, with Princess Astrid Coast of Queen Maud Land to the south. The depth varies between 3000 and $4500 \mathrm{~m}$. During most of the year, drift ice and numerous icebergs prevails in the sea. The Prydz Bay is an embayment between $66^{\circ} \mathrm{E}$ and $79^{\circ} \mathrm{E}$, which is bounded by the Amery Ice Shelf on the southwestern side, the Ingrid Christensen Coast on the southeast, and by Mac Robertson Land to the west. The depth varies from 200 to $300 \mathrm{~m}$ near the shelf edge on eastern side, to $1000 \mathrm{~m}$ off the Ingrid Christensen Coast. Surface circulation is characterized by a closed cyclonic gyre adjacent to

\section{Meteorological setting}

In the coastal region, cold continental polar air mass and relatively warm and moist maritime air masses converge to create thermal contrast which facilitates development of mesoscale systems. The highest cyclogenesis takes place during winter (Simmonds et al. 2003). The highest mesoscale cyclogenesis is associated with area of warm or cold air advection, low level baroclinicity and cyclonic vorticity over the region. The atmospheric circulation pattern around the Dronning Maud land consists of one or two high pressure systems extending in the meridional direction along the axis $10^{\circ} \mathrm{W}$ to $50^{\circ} \mathrm{E}$. A quasi-stationary pressure system near the coastal area prevails between these high pressure systems

\section{Physical Oceanography}

The WG is one of the main oceanographic features in the Southern Ocean. The WG role in the SO has been reviewed by Vernet et al. (2019). In spite of the fact that WG is considered as the main source of AABW production, recent studies sug- the Amery Ice Shelf (Smith et al. 1984), with inflow of cold water from the east near the West Ice Shelf and outflow near Cape Darnley. Studies show that the formation of dense shelf water occurs in the Cape Darnley Polynya $\left(65^{\circ}-69^{\circ} \mathrm{E}\right)$ and it subsequently transforms into Antarctic Bottom Water (AABW) (Ohshima et al. 2013). Because of the characteristic bathymetry, the Prydz bay holds a relatively small volume of highly saline deep water (Smith et al. 1984). It receives major glacial drainage from Lambert glacier-Amery Ice Shelf system and Sorsedal Glacier in the Ingrid Christensen Coast. The Antarctic Coastal Current flows westward around the Antarctic continent (Deacon 1937).

which are maintained by low pressure over the ocean. The branches of the meridional cyclone trajectories cover most parts of the Schirmacher Oasis. The South African branch of the cyclone trajectories moving along the east Antarctica coast enters deeper inland and produces a significant weather in the coastal areas of the Oasis (Mohapatra 2011). The precipitation occurs in the form of snow $(\sim 500 \mathrm{~mm}$ water equivalent per year), which varies with extreme events induced by the katabatic winds and the weather systems. The air-sea-ice interaction marked by a high latent heat loss at key locations along the Antarctic margins (for example, Cape Darnley) plays a key role in the formation of the AABW.

gest that up to $50 \%$ of the AABW exported across the northern rim of the gyre is imported into the gyre from the Indian sector of the SO (Jullion et al. 2014, Naveira Garabato et al. 2014). 
The vertical structures of temperature and salinity showed a strong influence of the wind-driven, cyclonic Weddell Sea circulation, wherein the fresh and cold water is advected eastward to about $20^{\circ}-30^{\circ} \mathrm{E}$ (Fig. 2). The vertical extent of the fresh water influx was about $300 \mathrm{~m}$. Likewise, in the Prydz Bay, the up-sloping of isohalines, low temperature $\left(-0.25^{\circ} \mathrm{C}\right)$ and densest water $>1027.7 \mathrm{~kg} \mathrm{~m}^{-3}$ at surface are signatures of increased salt rejection during ice formation and entrainment of saltier, low-oxygen CDW into the mixed layer during the winter convection (Gordon et al. 1984). The deep mixed layer exceeding $120 \mathrm{~m}$ depth (depth where density varies by $0.03 \mathrm{~kg} \mathrm{~m}^{-3}$ from that at $10 \mathrm{~m}$ value) was encountered at $50^{\circ} \mathrm{E}$. The stratification induced by influx of fresh and cold water maintained a shallow mixed layer depth $(50-70 \mathrm{~m})$ at the eastern and western sides of the transect. The voluminous water in the coastal Antarctica consisted of the CDW

\section{Biological-chemical characteristics}

A number of factors, including low sun angles, deep mixing of the upper water column, trace metal limitation, limitations of maximum photosynthetic efficiency by low water temperatures, and grazing pressure causes low primary production rates in $\mathrm{SO}$ waters (Martin et al. 1990). However, the glacial runoff carries large quantities of lithogenic particles in the freshwater derived from subglacial erosion and ice-free surface outwash into near-coastal and shelf areas. The runoff contributes the macronutrients $\left(\mathrm{NO}_{3}, \mathrm{SiO}_{4}\right)$, especially the bioavailable forms of iron (Hodson et al. 2017) to the coastal water that modifies physical and chemical characteristics of the upper ocean. High Chl- $a$ patches $\left(2-4 \mathrm{mg} \mathrm{m}^{-3}\right)$ are very common in austral summer in the Prydz Bay due to stratification that traps phytoplankton in a shallow mixed layer $\left(\theta=0.61{ }^{\circ} \mathrm{C}, S=34.68 \mathrm{psu}\right)$, which was detected between 50 and $100 \mathrm{~m}$, spanning $10^{\circ}$ and $45^{\circ} \mathrm{E}$, and at deeper depth $(>180 \mathrm{~m})$ between $58^{\circ}$ and $70^{\circ} \mathrm{E}$. Traces of AABW $\left(\theta=-0.51^{\circ} \mathrm{C}, S=34.66 \mathrm{psu}\right)$ were encountered at deeper depths $(>900 \mathrm{~m})$. The presence of super cooled water $(\theta=-2.14$ to $\left.-1.96^{\circ} \mathrm{C}, S=34.39-34.46 \mathrm{psu}\right)$ was detected in the region north of the Amery Ice Shelf front. These are caused by melting of ice beneath the sea ice layer where the freezing point is lowered due to high pressure (Shi et al. 2011). The production of high-salinity shelf water within the Prydz Bay is due to the absence of broad shelf areas attributed to its geography and bathymetry (Smith et al. 1984). Another feature observed is the freshening of AABW during 2006 to 2016 due to increase in temperature $\left(\sim 0.05^{\circ} \mathrm{C}\right)$ and reduced salinity $(\sim 0.01 \mathrm{psu})$ which makes it lighter $(\sim 0.01$ $\mathrm{kg} \mathrm{m}^{-3}$ ) (Anilkumar et al. 2015, Menezes et al. 2017).

(Fig. 2), where they are exposed to higher irradiances of the PAR. Elsewhere $\left(60^{\circ} \mathrm{S}\right.$, $47-49^{\circ} \mathrm{E}$ ), an intense phytoplankton bloom with Chl- $a$ in the range of $0.53-0.76$ $\mathrm{mg} \mathrm{m}^{-3}$, associated with intense deep Chl- $a$ maximum $\left(1.15 \mathrm{mg} \mathrm{m}^{-3}\right)$ at depths of $40-$ $60 \mathrm{~m}$ evolved during $16^{-17^{\text {th }}}$ February, 2011 (Sabu et al. 2014). In-situ observations close to the Antarctic coast (65.45 $65.53^{\circ} \mathrm{S}, 53.53-54.93^{\circ} \mathrm{E}$ ) show range of values for $\mathrm{NO}_{3}(29.13-37.37 \mu \mathrm{M}), \mathrm{SiO}_{4}$ $(67.82-82.26 \mu \mathrm{M}), \mathrm{PO}_{4}(2.17-2.54 \mu \mathrm{M})$, dissolved oxygen $\left(8.03-8.05 \mathrm{ml} \mathrm{l}^{-1}\right)$, PAR $\left(26.72-36.36 \mathrm{E} \mathrm{m}^{-2} \mathrm{~d}^{-1}\right)$, surface Chl- $a$ $\left(3.15-4.10 \mathrm{mg} \mathrm{m}^{-3}\right)$, column integrated Chl- $a\left(183.75-265.63 \mathrm{mg} \mathrm{m}^{-3}\right)$, surface primary productivity (PP, $7.90-19.83$ $\mathrm{mg} \mathrm{cm} \mathrm{c}^{-3} \mathrm{~d}^{-1}$, and column integrated PP $\left(397.15-1083.5 \mathrm{mg} \mathrm{cm}^{-3} \mathrm{~d}^{-1}\right)$ for February 2010 (Tripathy et al. 2014). 


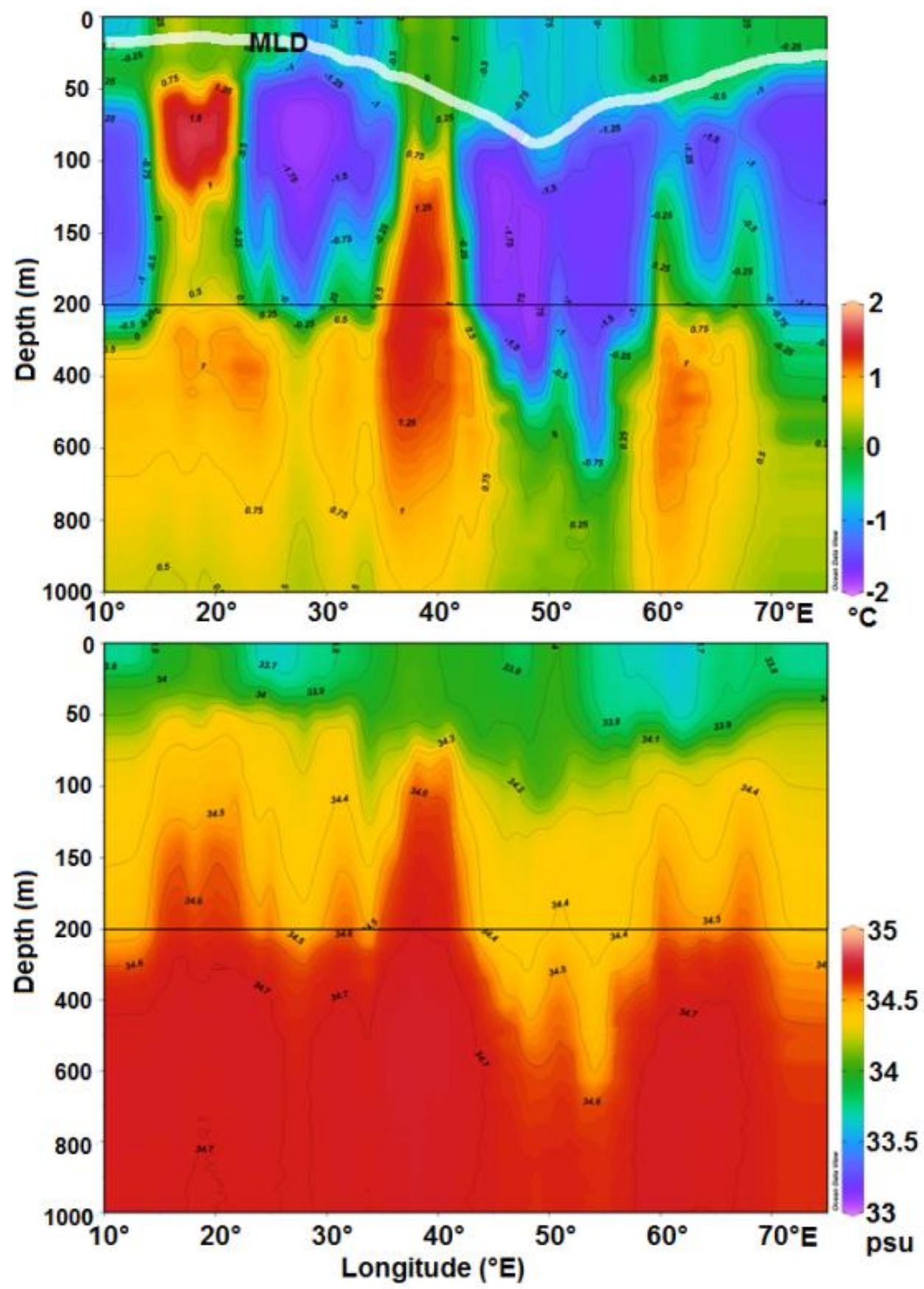

Fig. 2. Vertical structure of temperature and salinity for January 2019. The mixed layer depth is shown as white contour. 
The phytoplankton communities include diatoms $(59 \%)$ followed by flagellates $(40 \%)$ and prokaryotes $(1 \%)$. Tripathy et al. (2014) reported a decrease in Chl- $a$ specific PP in the surface layer. They hypothesized it to be due to the onset of pigment packaging effect, which is pronounced in large/micro phytoplankton (diatoms) compared to the nano- or pico-sized one (Tripathy et al. 2014). Due to limitations in sampling of phytoplankton and zooplankton from the cargo ship chartered for the expeditions, we infer results from previous expeditions. Euphausids is a major Antarctic zooplankton south of $60^{\circ} \mathrm{S}$, and E. superba contributes largely to the zooplankton fauna in the Indian Ocean sector of SO (Ingole and Parulekar 1993). Recently, community structure of zooplankton was assessed in the frontal zones of the Indian sector of the SO by Venkataramana et al. (2020). They report several copepods species (Ctenocalanus citer, Clausocalanus spp., Calanoides acutus, Calanus propinquus, Calanus australis and Rhincalanus gigas) that contribute to over $62 \%$ of the community structure at the Polar front.

During the Antarctic expeditions (1982 -1987), reported biomass of adult krill ranged between 6 and $305 \mathrm{ml} / 1000 \mathrm{~m}^{3}$, in the upper $200 \mathrm{~m}$ of the water column. The highest biomass of $684 \mathrm{ml} / 1000 \mathrm{~m}^{3}$ was

\section{Future directions}

Continuous monitoring of bio-physical and chemical parameters is required for understanding the PP and their linkages to climate variables: how the increased glacial melt may change the PP pattern in the scenario where the SAM is positive (resulting in northward horizontal advection) and in situation where localized warming is enhancing the glacial discharge. In-situ measurements should be done in the Antarctic zone to understand the role macronutrients and iron in both phytoplankton growth and bloom formation. Furthermore, since there are substantial seasonal variation in ocean- encountered in the shelf region during January 1987. Krill contributed largely $(>60 \%)$ to the total zooplankton biomass in the Queen Maud Land shelf region. Time series observations (down to $100 \mathrm{~m}$ ) carried out in the Prydz Bay using submersible fluorescence probe during February 2006 indicates phytoplankton community is dominated by diatoms, whereas cryptophytes are in low concentration due to high salinity and well mixed water column (Mohan et al. 2009). The maximum concentration of column-averaged chlorophyll was estimated to be $14.87 \mathrm{mg} \mathrm{m}^{-3}$ which is attributed to upwelling of subsurface winter water induced by local wind forcing, availability of micro-nutrients and increased attenuation of PAR. The concentration of blue-green algae was low when compared to that of green algae due to low temperature. High concentration of yellow substances was found due to the influence of melt-water from the continent. Variable phytoplankton concentrations in the time series suggest that the coastal waters of the Prydz Bay are influenced by changing subsurface water temperature and salinity due to wind-induced upwelling and also melting/freezing processes in late summer. The productivity is high in coastal water due to the input of macro as well as micro-nutrients.

ic $\mathrm{CO}_{2}$ in $\mathrm{SO}$ (e.g. Shetye et al. 2015, Xu et al. 2019), detailed $\mathrm{CO}_{2}$ measurements are required so as to better understand the implications of large blooms on $\mathrm{CO}_{2}$ sequestration. Recently, a notable growth of the $\mathrm{CO}_{2}$ sink in $\mathrm{SO}$ is reported (Munro et al. 2015). Therefore, the future $\mathrm{CO}_{2}$ measurements are necessary to prove this trend. Additionally, seasonal $\mathrm{CO}_{2}$ measurements following the approaches applied in the study of Shetye et al. (2015) are required for better understanding of the implications of large blooms on $\mathrm{CO}_{2}$ sequestration. 


\section{References}

Anilkumar, N., Chacko, R., Sabu, P. and George, J. V. (2015): Freshening of Antarctic Bottom Water in the Indian Ocean sector of Southern Ocean, Deep-Sea Research Part II, 118: 162-169.

Deacon, G. E. R. (1937): The hydrology of the Southern Ocean. Discovery Reports, 15: 1-24.

Gordon, A. L., Chen, C. T. A. and Metcalf, C. T. A. (1984): Winter mixed layer entrainment of Weddell Deep Water. Journal of Geophysical Research, 89: 637-640.

Hodson, A., Nowak, A., ŠabackÁ, M., Jungblut, A., Navarro, F., Pearce, D., Convey, P. and VIEIRA, G. (2017): Climatically sensitive transfer of iron to maritime Antarctic ecosystems by surface runoff. Nature Communications, 8: 14499. doi:10.1038/ncomms 14499

Ingole, B. S., PARUlekar, A. H. (1993): Zooplankton biomass and abundance of Antarctic krill Euphausia superba DANA in Indian Ocean sector of the Southern Ocean. Journal of Biosciences, 18(1): 141-148.

Jullion, L., Garabato, A. C. N., Bacon, S., Meredith, M. P., Brown, P. J., Torres - Valdés, S., Speer, K.G., Holland, P.R., Dong, J., Bakker, D., Hoppema. M., Loose, B., Venables, H. J., Jenkins, W.J., Messias, M.- J. and Fahrbach, E. (2014): The contribution of the Weddell Gyre to the lower limb of the Global Overturning Circulation. Journal of Geophysical Research: Oceans, 119: 3357-3377.

Martin, J. H., Gordon, R. M. and Fitzwater, S. E. (1990): Iron in Antarctic waters. Nature, 345(6271): 156-158.

Menezes, V. V., Macdonald, A. M. and Schatzman, C. (2017): Accelerated freshening of Antarctic Bottom Water over the last decade in the Southern Indian Ocean. Science Advances, 3(1), doi: 10.1126/sciadv. 1601426

Mohan, R., Shukla, S. K., Anilkumar, N., Sudhakar, M., Prakash, S. and Ramesh, R. (2009): Relative microalgal concentration in Prydz Bay, east Antarctica during late austral summer, 2006. Algae, 24(3): 139-147.

Mohapatra, M. (2011): Weather and weather system at Schirmachar Oasis (Maitri) - A review during past two decades. Mausam, 62(4): 513-534.

Munro, D. R., Lovenduski, N. S., Takahashi, T., Stephens, B. B., Newberger, T. and SwEENEY, C. (2015): Recent evidence for a strengthening $\mathrm{CO}_{2}$ sink in the Southern Ocean from carbonate system measurements in the Drake Passage (2002-2015). Geophysical Research Letters, 42: 7623-7630.

Naveira Garabato, A. C., Williams, A. P. and Bacon, S. (2014): The three-dimensional overturning circulation of the Southern Ocean during the WOCE era. Progress in Oceangraphy, 120: 41-78. https://doi.org/10.1016/j.pocean.2013.07.018

Ohshima, K. I., Fukamachi, Y., Williams, G. D., Nihashi, S., Roquet, F., Kitade, Y., Tamura, T., Hirano, D., Herraiz-Borreguero, L., Field, I., Hindell, M., Aoki, S. and Wakatsuchi, M. (2013): Antarctic Bottom Water production by intense sea-ice formation in the Cape Darnley polynya. Nature Geoscience, 6: 235-240.

Sabu, P., Anilkumar, N., George, J. V., Chacko, R., Tripathy, S. C. and Achuthankutty, C. T. (2014) The influence of air-sea-ice interactions on an anomalous phytoplankton bloom in the Indian Ocean sector of the Antarctic Zone of the Southern Ocean during the austral summer 2011. Polar Science, 8(4): 370-384.

Shetye, S., Mohan, R., Patil, S., Jena. B., Chacko, R., George, J.V., Noronha, S., Singh, N., PRIYA, L. and SudHAKAR, M. (2015): Oceanic pCO2 in the Indian sector of the Southern Ocean during the austral summer-winter transition phase. Deep Sea Research Part II Topical Studies in Oceanography 118. doi: 10.1016/j.dsr2.2015.05.017

Shi, J., Cheng, Y., Yutian, J. and Hou, J. (2011): Supercooled water in austral summer in Prydz Bay, Antarctica. Chinese Journal of Oceanology and Limnology, 29(2): 427-437.

Simmonds, I., KeAY, K. and Lim, E.-P. (2003): Synoptic activity in Sea around Antarctica. Monthly Weather Review, 131: 272-288.

SMith, N. R., ZhaOQIAN, D. J., KeRRY, K. R. and Wright, S. (1984): Water masses and circulation in the region of Prydz Bay, Antarctica. Deep-Sea Research I, 31: 1121-1147. 
Tripathy, S. C., Pavithran, S., Sabu, P., Naik, R. K., Noronha, S. B., Bhaskar, P. V. and ANILKUMAR, N. (2014): Is primary productivity in the Indian Ocean sector of Southern Ocean affected by pigment packaging effect? Current Science, 107(6): 1019-2016.

Venkataramana, V., Anilkumar, N., Swadling, K., Mishra, R. K., Tripathy, S. C., Sarkar, A., Soares, M.A, Sabu, P. and Pillai, H. U. K. (2020): Distribution of zooplankton in the Indian sector of the Southern Ocean. Antarctic Science, 32(3): 168-179.

Vernet, M., Geibert, W., Hoppema, M., Brown, P. J., HaAs, C., Hellmer, H. H., Jokat, W., Jullion, L., Mazloff1, M., Bakker, D.C.E. Brearley, J.A., Croot, P., Hattermann, T., Hauck, J., Hillenbrand, C. - D., Hoppe, C. J. M., Huhn, O., Koch, B. P.O., Lechtenfeld, J., Meredith, M. P., Garabato, A. C. N., Nöthig, E. - M., Peeken, I., Van Der Loeff, M.M.R., Schmidtko, S., Schröder, M., Strass, V. H., Torres - ValdÉs, S. and Verdy, A. (2019): The Weddell Gyre, Southern Ocean: Present Knowledge and Future Challenges. Reviews of Geophysics, 57: 623-708. https://doi.org/10.1029/2018RG000604

Xu, S., PArK, K., Wang, Y., Chen, L., Qi, D. and Li, B. (2019): Variations in the summer oceanic pCO2 and carbon sink in Prydz Bay using the self-organizing map analysis approach. Biogeosciences, 16: 797-810. https://doi.org/ 10.5194/bg-16-797-2019 